\title{
The Muscadine Grape: Botany, Viticulture, History, and Current Industry
}

\author{
William C. Olien ${ }^{1}$ \\ U.S. Department of Agriculture-Agricultural Research Service, Small Fruit Research Station, Box 287, \\ Poplarville, MS 39470
}

The muscadine grape (Vitis rotundifolia Michx.) was the first American grape species to be cultivated. This fruit has a long history in commercial and backyard culture. Picking muscadines to enjoy as juice along with muscadine pie on grandmother's back porch has a strong place in childhood memories of many native Southerners. The oldest and most consistent commercial interest in muscadines has been in wine, but juice and fresh fruit markets have also been developed. Muscadines so differ from "bunch" grapes genetically, anatomically, physiologically, and in taste that they should be considered a separate fruit.

The muscadine industry is currently expanding throughout the southeastern U.S. as interest in grapes and wine increases nationally. Commercial muscadine vineyards range in size from $<1$ ha to hundreds of hectares, and may be a primary or secondary source of income to the grower. There is particular interest in this fruit for small and part-time farm operations and as an alternative crop for agronomic growers. An important recent development has been the establishment of a major muscadine juice and processing plant in Mississippi with a satellite plant in North Carolina. Growth of the muscadine industry is supported by research to improve vineyard management, processing methods, and cultivars through breeding.

\section{BOTANICAL BACKGROUND}

Most authorities divide Vitis into the subgenera Euvitis Planch. (the familiar European and American bunch grapes that include $V$. vinifera L. and V. labrusca L.) and Muscadinia Planch. (sometimes referred to as berry grapes) (Dearing, 1938; Winkler et al., 1974). However, there has been a long-standing controversy, with some authors placing Muscadinia as a separate genus (Bouquet, 1980; Olmo, 1986; Small, 1913). Fossil evidence suggests that Muscadinia was widely distributed over the North American, European, and Asian continents before the last ice age (Bouquet, 1980). Thus, Muscadinia may be an ancestral genus that led to vitis, adapted to temperate climates,. and Ampelocissus, adapted to tropical climates, as the ice age receded. A wild

Received for publication 19 May 1989. The cost of publishing this paper was defrayed in part by the payment of page charges. Under postal regulations, this paper therefore must be hereby marked advertisement tsolely to indicate this fact:

${ }^{1}$ Present address: Dept. of Horticulture, Clemson Univ., Clemson, SC 29634-0375. grape found in India has similar characteristics to the Muscudinia (Syamal and Patel, 1953) and may reflect the pre-ice age distribution of this group.

Muscadinia grapes have 40 somatic chromosomes $(2 x=2 n=40)$ and are characterized by fruit borne in many clusters with few berries per cluster, formation of an abscission zone between the fruit and rachis, smooth thin bark that is adherent on young wood and separates in scales from older wood, unbranched tendrils, dense wood, and continuous pith (L.H. Bailey Hortorium, 1976; Einset and Pratt, 1975; Hedrick, 1908; Munson, 1909; Williams, 1923). In contrast, Euvitis grapes have 38 somatic chromosomes $(2 \mathrm{x}=2 \mathrm{n}=38)$, branched tendrils, many berries per fruit cluster, no abscission zone between the berry and rachis, striated bark on young wood, thick rough bark that peels in strips on old wood, less-dense wood than Muscudinia, and pith interrupted by diaphragms at nodes.

Muscudinia is a much smaller group than Euvitis, and is comprised of three known species. Vitis munsoniana Simpson ex Munson (common names Bird Grape, Everbearing Grape, Mustang Grape, Little Muscadine Grape) and $V$. popenoei Fennell (common name, Mexican Muscadine Grape) (Munson, 1908; U.S. Dept. of Agriculture, 1973; Weaver, 1976; Winkler et al., 1974) are not important commercially, but are possible sources of genetic variation for breeding programs. Vitis munsoniana is likely a semitropical variant of $V$. rotundifolia, native to Florida and a narrow coastal band along the Gulf of Mexico from Florida to Texas (Husmann and Dearing, 1916). Vitis munsoniana bears clusters of eight to 30 relatively small berries with thin skin and small seeds, but poor fruit quality (Dearing, 1947). Vitis popenoei is a tropical species native to southern Mexico (Fennell, 1940).

The third species, $V$. rotundifolia Michx. (common names: Muscadine, Bullace, Bull Grape, Bullet Grape, Southern Fox Grape), is the only commercial Muscadinia grape, and the name "muscadine" is reserved exclusively for this species. The majority of $V$. rotundifolia vines in the wild bear dark fruit. A very old name for these grapes is "Bullace" or "Bullis", or less commonly "Bull" or "Bullet" grapes (Gohdes, 1983; Hedrick, 1908). Light-colored bronze-fruited genotypes are occasionally found in the wild and are often referred to generically as "scuppernongs". However, there are many cultivars of bronze muscadines, and 'Scuppernong' is the name of a specific cultivar.

The natural range of $V$. rotundifolia extends from Delaware to central Florida and along the Gulf of Mexico to eastern Texas (L.H. Bailey Hortorium, 1976; Dearing, 1938; Munson, 1909; Weaver, 1976). The species extends north along the Mississippi River to Missouri and near the Appalachian Mountains from the east and west. Temperatures in this region seldom go lower than - 12C and more rarely to - 18C (U.S. Dept. of Agriculture, 1973). These vines do best on fertile sandy loams and alluvial soils, and grow poorly on wet and heavy soils. Natural populations are found in shady, well-drained bottom lands along rivers that are subject to neither extended drought nor waterlogging (Hedrick, 1908; Munson, 1909).

Wild $V$. rotundifolia vines are functionally dioecious (polygamous) due to incomplete stamen formation in female vines and incomplete pistil formation in male vines (Dearing, 1948; Hedrick, 1908). Male vines account for $60 \%$ to $75 \%$ of the wild muscadine population (Dearing, 1938; Husmann and Dearing, 1916). Female vines bear fruit in numerous clusters of from one to 40, but more commonly four to 10 , thick-skinned berries containing two to six large seeds (Husmann and Dearing, 1916; Young, 1920). The vines are late in breaking bud in the spring and require a long season, generally $>100$ days, to mature the fruit (Hedrick, 1908).

\section{EARLY MUSCADINE CULTIVARS}

Muscadines have long been harvested from wild and semicultivated vines (Hedrick, 1908). According to Hedrick, Native Americans used the fruit, and the earliest Europeans to reach America noted the abundance of $V$. rotundifolia. Captain John Hopkins reported that Spanish missionaries in Florida were making muscadine wine in 1565 . He also noted that Amadas and Barlowe reported the abundance of these grapes in coastal North Carolina on their first voyage to this continent in 1584. The latter described the land "so full of grapes ... on the sand and on the green soil, on the hills as on the plains, as well as on every little shrub as also climbing towards the tops of tall cedars, that I think in all the world the like abundance is not to be found".

Muscadines have been cultivated in vineyards since the mid-18th century (Reimer, 1909). The first cultivars were simply selections propagated from the wild (Reimer, 1909). Although there were 35 to 40 named muscadine cultivars in 1920 , only a few were 
grown extensively (Young, 1920). Betterknown early cultivars and approximate dates introduced were 'Hopkins' (1845), 'Flowers' (1800), 'James' (1866), 'Memory' (1868), 'Mish' (or 'Meisch') (1846), 'Scuppernong' (mid-1700s), and 'Thomas' (1845) (Husmann and Dearing, 1916; Reimer, 1909). All early cultivars were female types and required pollinator vines for optimum fruit set (Young, 1920).

The cultivar eventually named 'Scuppernong' was the first native American grape to be cultivated (Hedrick, 1908; Reimer, 1909). 'Scuppernong' was the dominant cultivar 'grown from the mid-18th century until as recently as 1947 , and it remains the most widely known muscadine (Reimer, 1909; Dearing, 1947; Woodroof, 1934). Popular culture often gives credit for discovery of the original 'Scuppernong' vine to Sir Walter Raleigh's colony when they landed on Roanoke Island, N.C. (Gohdes, 1982; Hedrick, 1908). However, Reimer (1909) concluded that the original 'Scuppemong' vine was found by Isaac Alexander in the mid-18th century along the Scuppernong River in Tyrrell County, N.C. The vine was soon widely propagated and was likely carried to Roanoke Island some time in the late 18th century. This cultivar was initially known by several names, especially the "Big White Grape", and it was not until 1811 that the name 'Scuppernong' was assigned by Calvin Jones, an editor for The Star newspaper of Raleigh, N.C. The name was chosen because of the numerous plantings of this grape along the Scuppernong River and around Lake Scuppernong. The word scuppernong is apparently a corruption of "ascuponung", an Algonquin Indian word for "place of the Sweet Bay plant" [Magnolia virginiana L. (M. glauca L.)], found abundantly along the Scuppernong River.

'Scuppernong' was especially valued for its hardiness, tolerance of neglect, and quality as a table and wine grape. Bronze muscadines were soon recognized as superior for wine because the nonacylated diglucoside anthocyanin pigments of dark muscadine grapes are unstable and easily oxidized, in contrast to the monoglucoside and acylated monoglucoside anthocyanin pigments of $\mathrm{Eu}$ vitis grapes (Ballinger et al., 1974). Recently, wild muscadine genotypes have been identified with mono- and diglucoside forms of anthocyanin pigments (Goldy et al., 1989). Continuous vegetative propagation of this cultivar for nearly 250 years, and probable introduction of other bronze muscadines under the same name, has resulted in the formation of a number of strains of 'Scuppernong' (Woodroof,. 1934). 'Scuppernong' vines in production have been reported as old as 150 years (U.S. Dept. of Agriculture, 1973).

\section{BREEDING PROGRAMS}

Breeding programs to obtain improved cultivars were initiated at Willard, N.C., around 1907 by Dearing (1917) and Detjen (1917a) as a cooperative effort between the USDA-ARS and North Carolina State Univ. and continues today as a university project.
A second USDA-ARS muscadine breeding program was conducted at Meridian, Miss., from 1941-1965 by N.H. Loomis. Muscadine breeding was initiated by the Georgia Experiment Station in 1909 (Stucky, 1919). In addition, various private individuals have conducted muscadine breeding efforts, most notably the Euvitis $x \mathrm{~V}$. rotundifolia hybridization efforts of T.V. Munson (1909) in Texas, and Olmo (1986) and coworkers in California. Active muscadine breeding programs for fruiting cultivars are currently being conducted in Florida (Bates et al., 1980; Mortensen, 1971), Georgia (Lane, 1978), and North Carolina (Goldy, 1988; Goldy et al., 1988). Progress in breeding up to the early 1970s was summarized by Einset and Pratt (1975) and Schwartz (1976). 'Hunt' was introduced in 1920 by the Georgia Experiment Station (Stucky, 1919) and had improved yield and fruit quality, but was female and required companion pollinators. The development of perfect-flowered, self-fertile cultivars was a major goal of early breeding programs. The first self-fertile genotypes were reported by the North CarolinaUSDA breeding program in 1917 and the first cultivars were released in 1948 (Dearing, 1917, 1948).

A long-standing goal of both Euvitis and $V$. rotundifolia breeding programs has been development of hybrids between these groups, combining fruit quality from $V$. vinifera with disease resistance and environmental adaptation of muscadines (Bouquet, 1980; Einset and Pratt, 1975; Goldy et al., 1988; Lane, 1978; Munson, 1909; Olmo, 1986). Hybridization is difficult due to differences in chromosome number, but has been successful when the muscadine was used as the male parent (Davidis and Olmo, 1964). Most hybrids have been sterile, but a few have a low level of fertility. In addition to standard breeding techniques, tissue culture and protoplast fusion methods are being employed with the hope of developing fruitful hybrids through backcrossing programs to develop both $V$. vinifera and $V$. rotundifolia cultivar types (Goldy et al., 1988; D. Gray, personal communication; Lee and Wetzstein, 1988). No Euvitis x Muscadinia hybrids have been released as fruiting cultivars, but two hybrids were recently released as disease-resistant rootstocks for Euvitis grapes (Lider et al., 1988a, 1988b; Walker et al., 1989).

The development of a seedless muscadine for table use is a major goal in current breeding programs. Embryo rescue from standard sexual crosses of seedless Euvitis grapes (female parent) and $V$. rotundifolia (pollen parent) (Goldy et al., 1988), and protoplast fusion methods (D. Gray, personal communication; Lee and Wetzstein, 1988) are being used in an effort to develop seedless hybrids with $V$. rotundifolia character.

\section{MUSCADINE CULTURE AND PHYSIOLOGY}

Propagation. Muscadine grapes are not grown on rootstocks, and are incompatible as rootstocks for Euvitis grapes (Davidis and Olmo, 1964; Husmann and Dearing, 1916; Winkler et al., 1974). In contrast to Euvitis, muscadines root poorly from woody cuttings (Goode et al., 1982; Husmann and Dearing, 1916). Commercial practice is to propagate either by layering (Woodroof, 1936) or by mist-propagation of softwood cuttings (Goode and Lane, 1983). 1H-indole-3-butyric acid (IBA) increased root system quality of cuttings taken prior to July, but did not increase root initiation or shoot growth (Goode and Lane, 1983). Vines are sold bare-root or in "1-gallon" (3.8liter) nursery pots. Micropropagation methods are currently being developed by several groups (Gray and Fisher, 1985; Griffin and Graves, 1989; Lee and Wetzstein, 1989; Sudarsono and Goldy, 1988).

Planting and establishment. General recommendations on site selection, soil preparation, planting methods, and vineyard management are given in several muscadine production manuals (Hegwood et al., 1983; Ferree et al., 1983; Poling et al., 1987; U.S. Dept. of Agriculture, 1973). While mature muscadine vines are noted for vigorous growth, they can be difficult to establish after planting (Husmann and Dearing, 1916). Recent studies have determined that size, shape, and wall roughness of the planting hole, and severity of summer pruning in first-season vine training, have a marked effect on establishment and growth of muscadines (Olien, 1989).

Training and trellis. Traditionally, muscadines were grown on extensive overhead arbor systems, often without pruning or management (Husmann and Dearing, 1916; Newman, 1907). Arbor height was typically $2.1 \mathrm{~m}$, with eight arms radiating out from single trunks, spaced at 4.6 x $4.6 \mathrm{~m}$. Newman (1907) recommended a four-wire vertical trellis (4-WVT) over the arbor system for commercial production because it was easier to manage and harvest. However, the vigorous growth habit of muscadines soon led to recommendations of two or three wires in vertical systems to reduce shading of lower cordons and consequent increase in growth, yield, and fruit quality (Dearing, 1938; Husmann and Dearing, 1916; Savage, 1941; Young, 1920). Generally recommended spacing was 6.1 to $6.7 \mathrm{~m}$ in-row and 3.7 to $4.6 \mathrm{~m}$ between rows. In a 20 -year study, Brightwell and Austin (1975a) found that long-term yields of 'Hunt' were lowest on single-wire trellis, intermediate on a 2-WVT, and highest on the arbor system, if managed with adequate pruning. However, highest yield in the first two bearing years was obtained with the 2-WVT system, an important advantage in generating income to offset establishment costs. In-row vine spacing from 6.1 to $6.7 \mathrm{~m}$ had no effect on yield/area, but between-row spacing of $3.0 \mathrm{~m}$ gave higher longterm yields/area than either 3.7 or $4.3 \mathrm{~m}$ between rows (Austin and Bondari, 1989; Brightwell and Austin, 1975b). When a twowire horizontal trellis, based on Geneva Double Curtain (GDC), was compared with 2WVT, the GDC system averaged $11 \%$ greater yields and $0.6^{\circ}$ Brix higher soluble solids for 31 cultivars over the first 3 to 5 crop years (Andersen et al., 1985; Andrews, 1981). R.P. 
Lane (personal communication) noted a $63 \%$ yield increase for GDC over a single-wire trellis, but pruning costs were 29.7 and 7.4 working hours/ha (12 and $3 \mathrm{hr} / \mathrm{acre}$ ), respectively. Muscadines grown on GDC are not maintained as two separate "curtains", but shoots from parallel cordons are allowed to grow together. This arrangement creates a shaded, humid canopy in the fruiting zone and in some regions results in an unacceptable amount of fruit rot (G.W. Krewer, personal communication). Some growers have hedged the lateral shoots to near the fruiting zone soon after veraison to aid spray penetration and decrease canopy humidity. There have been no research evaluations of the possible benefits or hazards (such as increasing risk of fall cold injury) of this practice. Leaf removal has become a standard practice to reduce canopy density of bunch grapes (Winkler et al., 1974), but this has not been tried in muscadines.

In current commercial production, muscadines are trained to single trunks with permanent cordons on 1- or 2-WVT or on GDC. The most common spacing is $3.7 \mathrm{~m}$ between rows $\times 6.1 \mathrm{~m}$ in the row. Optimum trellis design and training system depends on a balance of management costs, yield, and price per tonne of fruit. The GDC system is recommended in Mississippi (C.P. Hegwood, personal communication), while the single-wire trellis is most commonly recommended in Florida, Georgia, and the Carolinas (R.G. Goldy, R.P. Lane, and J.A. Mortensen, personal communication).

Management of fruiting wood. Dormant pruning was originally believed to be injurious, but several early authors disputed this claim (Husmann and Dearing, 1916; Newman, 1907; Reimer, 1909; Young, 1920). According to Dearing (1938), lack of pruning decreased fruit quality and increased alternate bearing, early defoliation, and susceptibility to winter injury. Late winter or early spring pruning results in highly visible "bleeding" of sap from pruning wounds. Newman (1907) noted heavy bleeding in vines pruned in February or later and recommended pruning earlier than this, believing that excessive bleeding is detrimental. He collected as much as $1.5 \mathrm{~kg}$ of sap per vine over 2 months from vines pruned 20 Mar. Late pruning has been reported to delay shoot and berry development and reduce yields (Newman, 1907; Onokpise and Inyang, 1987), but others found no decrease in yield with late pruning (Dearing, 1938; Loomis, 1943). Dearing (1938) concluded that pruning should be confined to the period between midwinter and bud swell. Increased susceptibility to winter injury has been noted following pruning before mid-winter (Dearing, 1938).

Early publications recommended pruning muscadines to short spur systems on permanent cordons. (Armstrong et al., 1934; Murphy et al., 1938; Savage et al., 1941), but supporting data were lacking. Loomis (1943) found higher yields in a 3-year trial when mature 'Scuppernong' and 'Thomas' vines were pruned to four-bud spurs in comparison to pruning to a six-cane Kniffen system with 2.3-m canes. In a 5-year study, there was no effect on yield when mature
'Thomas' were pruned to one-, two-, three-, or four-bud spurs or for mature 'Hunt' pruned to two- to four-bud spurs, with and without $50 \%$ spur thinning, or to seven- to eight-bud canes (Loomis et al., 1949). Lane (1977b) compared 10 cultivars over the first five fruiting years pruned to three-bud spurs or nine-bud canes, with equal number of buds retained in each treatment. Yield of vigorous cultivars was consistently greater with cane pruning. Other cultivars showed an occasional yield increase with cane pruning, but spur pruning was never superior in these young vines. Higher yields with cane pruning were a result of greater bearing surface. Results of this study also indicated the onset of alternate bearing in cane-pruned vines after the fourth treatment year. Annual pruning must be accompanied by regular spur thinning. Excessive spur development over several years leads to shading, poor canopy structure, and poor fruit quality, similar to the problems with no pruning (Lane, 1977b; Loomis et al., 1949).

Current practice is to prune to two- to fourbud spurs, up to six-bud spurs for vigorous shoots, in combination with occasional light spur thinning (Hegwood et al., 1983; Ferree et al., 1983; Poling et al., 1987; U.S. Dept. of Agriculture, 1973). Mechanical hedging with follow-up hand-pruning is practiced by growers with large operations. Mainland et al. (1982) reported that hedging a $20 \times 20$ $\mathrm{cm}$ square around the cordon without additional hand-pruning resulted in increasingly dense growth over 3 years that made harvest difficult. However, hedging to $20 \times 40-\mathrm{cm}$ and alternating the long axis between a horizontal and vertical direction each year maintained a manageable canopy without decreasing yield.

A further important task of dormant-pruning is removal of tendrils that encircle cordons or spurs. Muscadine tendrils become extremely tough and will girdle spurs and even the main cordon if not removed each year. Yield increases associated with pruning will be lost if equal care is not given to removal of circling tendrils (Hegwood et al., 1983; Ferree et al., 1983; Poling et al., 1987; U.S. Dept. of Agriculture, 1973).

New shoot growth and fruiting wood must be prevented from developing on the permanent trunk and arms leading up to the trellis wires, particularly for efficient mechanical harvest. An exception is the occasional need to train replacement trunks or cordons. Dearing (1938) recommended regular, systematic replacement of cordons over an 8-year period. New shoot growth is easily rubbed off by hand in the spring and early summer. Naphthaleneacetic acid in white latex paint has been used successfully to prevent shoot development on established trunks, while physical wraps prevented shoot development but induced root development on the trunk (Takeda et al., 1983).

Pollination and fruit set. Small vineyards of female cultivars might depend on male vines in adjacent woods, but commercial production of such cultivars requires planting male vines every third vine in every third row (Husmann and Dearing, 1916). Thus, before the development of perfect-flowered cultivars, $11 \%$ of the vineyard was occupied by nonbearing vines. Today, perfect-flowered cultivars are used as pollinizers, greatly increasing yields per hectare.

Muscadines pollen is dry and is probably transferred to pistillate cultivars almost entirely by insects (Dearing, 1938; Detjen, 1917b). Dearing (1938) reported that the most efficient pollinator is the small mining bee (Halictus stultus Cress.), followed by the green bee (Agapostemon splendens Lep.), gray bee (Magachile sp.), and small bumblebee (Bombus irnpatiens Cress.), and that the honeybee (Apis mellifica L.) is not an efficient pollinator of muscadines. Beetles have also been noted as possible muscadine pollinators, particularly Copidita thoracica F. and the soldier beetle (Chauliognathus marainatus F.) (Dearing, 1938; Detjen, 1917; Armstrong, 1936). Dearing (1938) estimated that fruit set of pistillate cultivars was normally $7 \%$ to $10 \%$, but could be increased to $20 \%$ to $30 \%$ with proper pollination. The primary means of pollen transfer in perfectflowered muscadine cultivars is not known. Winkler et al. (1974) concluded that selfpollination is the primary method of pollen transfer in $V$. vinifera grapes, and that insect and wind transfer of pollen were relatively unimportant. Various beetles and flies, but not bees, have been noted at anthesis in muscadine test vineyards in North Carolina (R.G. Goldy, personal communication). Fruit set in six perfect-flowered muscadine selections ranged from $11.3 \%$ to $23.3 \%$ (Goldy, 1988).

An initial set of berries develops opposite leaves at nodes 3 through 6 from the base of current season shoots, as in many grapes (Pratt, 1971). However, muscadines have a marked tendency to develop additional flower buds on lateral shoots that can flower and set fruit in the year they are initiated (Husmann and Dearing, 1916; Young, 1920). This tendency results in uneven ripening with fruit ranging from a few millimeters in diameter to fully mature at harvest. Berries from the initial fruit set ripen earliest and have the highest quality. The degree of secondary fruit development is affected by cultivar, vine age, management practices, and environmental conditions.

Fruit development. Muscadine berries appear to develop in the same manner as Euvitis grapes, following a double-sigmoidal growth curve (Carroll, 1985; Pratt, 1971). Sugar content and $\mathrm{pH}$ increase and acid content decreases as berries mature (Carroll, 1985). Although fruit size at maturity differs considerably with cultivar, perfect-flowered types tend to be smaller (average $4.7 \mathrm{~g} /$ berry, ranging from 2.2 to $7.4 \mathrm{~g}$ /berry) than pistillate-flowered types (average $5.8 \mathrm{~g} /$ berry, ranging from 2.8 to $15.0 \mathrm{~g}$ /berry) Andersen et al., 1985; Balerdi and Mortensen, 1969; Carroll, 1985; Hegwood et al., 1983; Moore and Bowden, 1976; Poling et al., 1985; Williams, 1954).

Muscadine berries form an abscission zone between the fruit and rachis (Sherman, 1963; Mitchell, 1979). In most cultivars, the berry matures before this abscission layer is fully formed, although there is variation among cul- 
tivars and years (Sherman, 1963). Fruit removal force has been positively correlated with juice soluble solids content in 'Carlos', 'Magnolia', 'Tarheel', and 'Noble' (Mitchell, 1979). When harvested, immature fruit abscission zones tend to tear, resulting in a "wet stem scar", tom skin, and leaking juice. Fruit in this condition deteriorate and decay rapidly. 'Carlos' is the best cultivar developed to date for stem scar rating, usually $10 \%$ wet scar at harvest, and is often used as the standard for evaluating new cultivars (Lane, 1977a, 1980; Lane and Bates, 1987; Mitchell, 1979). Other cultivars with high dry stem scar ratings are 'Golden Isles' (Lane and Bates, 1987), 'Southland' (Hegwood et al. 1983), 'Summit' (Lane, 1977a), 'Triumph' (Lane, 1980), and 'Thomas' (Sherman, 1963). 'Tarheel' tends to be intermediate in stem scar rating (Mitchell, 1979).

Harvest. With good vineyard management, muscadines will produce a commercial yield in the third year after planting and mature yields by the 6th to 7 th year (Dearing, 1938). Because of the tendency to shatter (abscise), muscadines are usually harvested as single berries (Mitchell, 1979). However, whole clusters of cultivars with less tendency to shatter, such as 'Fry' and 'Pride', may be clipped by hand for the fresh market (Lane, 1972). Traditionally, muscadines are harvested semimechanically. The trellis and vine arms are beaten with baseball bats, shaking the fruit off the vine onto-a tarp or canvas frame (Clark, 1981; U.S. Dept. of Agriculture, 1973). This method can damage the vine and fruit. Fruit bruised and covered with leaking juice due to harvest injury must be processed or sold fresh within a few days. Most mechanical harvesters operate in a similar manner to the semimechanical method and cause similar problems. A new mechanical harvester for muscadines is under development at Mississippi State Univ. This harvester vibrates the vine arms, rather than beating them, and shows promise for both processing and fresh-market muscadines. (2Chloroethyl)phosphonic acid (ethephon) has been used successfully as an aid to mechanical and semimechanical harvest of muscadines by promoting development of the fruit abscission layer (Lane and Flora, 1979; Mortensen, 1980; Phatak et al., 1980).

Average harvest date across all cultivars ranges from 24 Aug. in central Florida to 15 Sept. in Mississippi, Georgia, and the Carolinas (C.P. Hegwood, R.P. Lane, and J.A. Mortensen, personal communications). The period from flowering to harvest is fairly constant across production areas, varying from 106 to 113 days. Individual cultivars vary considerably in average harvest date, providing a harvest season of $» 30$ days.

Fruit yield. -Early in this century, yields of mature muscadine vines averaged 6.7 to $10.1 \mathrm{t} \cdot \mathrm{ha}^{-1}$, and ranged from 4.4 to 17.9 $\mathrm{t}^{-h^{-1}}{ }^{-1}$ depending on site, season, care, and cultivar (Husmann and Dearing, 1916). 'Scuppernong' was noted to produce low yields, averaging $5 \mathrm{t} \cdot \mathrm{ha}^{-1}$. Despite changes in cultivars and management practices, the average commercial yield has remained relatively unchanged. Yields over the south- eastern United States were reported to average 4.4 to $9.0 \mathrm{t} \cdot \mathrm{ha}^{-1}$ in 1973 (U.S. Dept. of Agriculture, 1973). North Carolina reported yields of $7.8 \mathrm{t} \cdot \mathrm{ha}^{-1}$ as recently as 1982 (Poling, 1982). However, many growers are achieving regular yields of $22 \mathrm{t} \cdot \mathrm{ha}^{-1}$. Yields in published cultivar trials vary widely, but better-yielding cultivars generally range from 11 to $34 \mathrm{t} \cdot \mathrm{ha}^{-1}$ at a vine spacing of $3.7 \times$ $6.0 \mathrm{~m}$ (e.g., Andersen et al., 1985; Balerdi and Mortensen, 1969; Goldy, 1988; Hegwood et al., 1983; Moore and Bowden, 1976). Yields of 'Doreen' have been recorded as high as $40 \mathrm{t}^{-h^{-1}}$ in cultivar trials (Hegwood et al., 1983).

Fruit quality and juice yield. Due to uneven ripening, methods of fruit sorting and grading would be particularly advantageous for fresh market sales. Successful grading into ripeness categories has been accomplished by a reflected light spectrophotometer (Ballinger et al., 1978) and by density separations in graded brine solutions (Lanier and Morris, 1979).

Factors affecting quality of juice, wine, and fresh use, and yields of juice per weight of berries, were recently reviewed by Carroll (1985). Muscadine juice tends to be lower in soluble solids concentration (SSC) and titratable acidity than $V$. labruscana and $V$. vinifera juice (Carroll, 1985). Sugar and acid frequently must be added to the juice to produce a wine with sufficient acid and alcohol content. Carroll (1985) listed major juice components and average concentrations for muscadine cultivars in current production as fructose $(5.51 \%)$, glucose $(5.16 \%)$, sucrose $(1.89 \%)$, malic acid $(0.50 \%)$, and tartaric acid $(0.36 \%)$. Soluble solids concentration averaged $13.2 \%$ (10\% to $18 \%$ ), titratable acidity (expressed as tartrate equivalent) $0.84 \%(0.39 \%$ to $1.5 \%)$, and $\mathrm{pH} 3.14$ (2.9 to 3.4). As with other American grapes, the significant sucrose content of muscadine juice is in contrast to the trace concentrations of sucrose in $V$. vinifera grapes. Grower contracts for sale of muscadines for juice production specify SSC of $13 \%$ to $15 \%$, with premiums paid for SSC up to $18 \%$ (R.T. Kahrer, personal communication). No mention is made of juice $\mathrm{pH}$ or titratable acidity. Flavor components are more highly correlated with juice $\mathrm{pH}$ than with titratable acidity or SSC (R.P. Vine, personal communication). Carroll (1985) stated that total acidity and $\mathrm{pH}$ are probably more critical than sugar content as a harvest index for wine production. He recommends harvesting at a total acidity above $0.5 \%$ and $\mathrm{pH}$ of 3.0 to 3.4. Bates et al. (1986) recommend muscadine harvest for wine before full maturity with juice $\mathrm{pH}$ of 3.0 to 3.5 . Harvesting by $\mathrm{pH}$ alone in the range of $\mathrm{pH} 3.1$ to 3.3 has been recommended for unfermented juice (R.P. Vine, personal communication).

Low juice yields per tonne of fruit due to thick skins and mucilaginous pulp is a second problem in processing muscadines (Harkness et al., 1987; Sims et al., 1988). Juice yields of muscadines range from $46 \%$ (w/w) to $54 \%$, as compared to $67 \%$ to $75 \%$ from 'Concord', using conventional crush- ing and pressing methods (Harkness et al., 1987). Effects of temperature during pressing and pressing aids (e.g., rice hulls) are being evaluated as a means to increase muscadine juice yield while maintaining juice quality (Harkness et al., 1987; Sims et al., 1988).

Vineyard floor management. Herbicide weed control in the row with grass alleys between rows has become standard practice, but bare soil can create problems in highly erodible sites. Early muscadine bulletins recommended intercropping "hoed" crops such as melons, tomatoes, peanuts, cotton, tobacco, and legume crops to add income, especially during the 3 to 5 years before significant 'yields were obtained from the muscadine vines (Husmann and Dearing, 1916). Cereals and corn were not recommended. Frequent cultivation has been used to develop a deep root-system, but this practice is no longer recommended because muscadines tend to be very shallow-rooted, even in well-drained soils. Current research on intercropping is being conducted to aid small farmers $(\mathrm{O}$. Bandele, personal communication). Interplanted clover is also being explored as a mulch and N source (C.P. Hegwood, personal communication).

Irrigation and fertility. Irrigation has been recommended only recently in the mid-Gulf of Mexico region (Hegwood et al., 1983), and is not common in the Carolinas and Georgia (Ferree et al., 1983, Poling et al., 1987). Austin and Bondari (1988) found considerable variation in yield response of mature 'Hunt' vines to drip-irrigation over 8 treatment years, and a significant interaction with fertility level. Yields of nonirrigated vines fertilized annually with $1.4 \mathrm{~kg} / \mathrm{plant}$ of $10 \mathrm{~N}-4 \mathrm{P}-8 \mathrm{~K}$ fertilizer were not significantly different from vines irrigated to maintain soil water potential $>15 \mathrm{kPa}$ at $15-$ and $45-\mathrm{cm}$ depths and fertilized with $0.9 \mathrm{~kg} / \mathrm{plant}$ of the same fertilizer. Irrigation markedly reduced alternate bearing.

Where used, irrigation is almost exclusively applied through drip systems. Irrigation is particularly important during the first 2 , years to hasten vine establishment and training (Hegwood et al., 1983). Bearing vineyards should be well-irrigated during the first part of the season to support shoot growth, flowering, and initial fruit set. However, after set of the primary crop, irrigation should be limited during the remainder of the season to reduce secondary fruit set and uneven ripening and to reduce late-season shoot growth, delayed dormancy, and susceptibility to winter injury.

Fertilizer recommendations for muscadines have been largely based on bunch grape practices (Hegwood et al., 1983; Ferree et al., 1983; Poling et al., 1987; U.S. Dept. of Agriculture, 1973). Muscadine fertility research prior to 1966 was largely concerned with Mg deficiency (Cook, 1966). Much of the muscadine production is on sandy soils with low cation exchange capacity and low $\mathrm{Mg}$ levels. Muscadines are particularly prone to $\mathrm{Mg}$ deficiency, and symptoms of interveinal leaf chlorosis are frequently apparent from the middle to end of the growing season 
(Lott, 1948; Hagler, 1949). The problem can be corrected by soil amendment, foliar application, or trunk injection of $\mathrm{MgSO}_{4}$ (Lott, 1948, 1952), but best results were obtained by foliar sprays of $\mathrm{MgCl}_{2}$ and $\mathrm{Mg}\left(\mathrm{NO}_{3}\right)_{2}$ (Hagler, 1957). Apparent yield responses to $\mathrm{B}$ application have been noted in Georgia, (Boswell et al., 1980). Ragland (1940) noted response to potash, but not nitrate or $\mathrm{P}$, in reversing symptoms of leaf yellowing and scorch in a mature muscadine vineyard. A series of papers by Cummings and co-workers in North Carolina reported considerable variation in leaf and fruit nutrient content through the season and between years (Cummings and Lilly, 1984, and papers cited therein). Optimum yields occurred over soil $\mathrm{pH}$ values of 5.5 to 7.0, and yield was increased at all $\mathrm{pH}$ levels by increasing annual $\mathrm{N}$ application from 50 to $83 \mathrm{~kg} \cdot \mathrm{ha}^{-\mathrm{9}}$ (Cummings and Lilly, 1984).

Diseases and pests. Muscadines have a high degree of resistance to pests and diseases, especially Pierce's disease (Xylella fastidiosa Wells et al.), which severely limits production of Euvitis species in the southeastern United States (Bouquet., 1980; Hedrick, 1908). Vitis rotundifolia is among the most resistant grape species to the grape phylloxera insect (Daktulosphaira vitifolia Fitch), which causes devastating root injury to $V$. vinifera (Husmann and Dearing, 1916). Muscadine pests noted early in this century were black rot [Guignardia bidwellii (Ellis) Viala \& Ravaz] and grapevine flea beetle (Altica chalybea Illiger) (Husmann and Dearing, 1916). As muscadines became more extensively planted, additional pests were recognized. Excellent descriptions of muscadine diseases and pests are contained in references by Pearson and Goheen (1988), McGiffen and Neunzig (1985), and Dutcher et al. (1989).

Primary disease problems of muscadines are fruit rots, especially black rot, bitter rot [Greeneria uvicola (Berk. \& Curt.) Punithalingam, syn. Melanconium fuligineum (Scribner \& Viala) Cav.], ripe rot [Colletotrichum gloeosporioides (Penz.) Penz. \& Sacc., teleomorph Glomerella cingulata (Stonem.) Spauld. \& Schrenk], and macrophoma rot [Botryosphaeria dothidea (Moug. ex Fr.) Ces. \& de Not., anamorph Macrophoma sp.] (Ferree et al., 1983; Hegwood et al., 1983; Jabco et al. 1985; Poling et al., 1987; Savage, 1941). If severe, angular leaf spot (Mycosphaerella angulata Jenkins) may cause leaf abscission, resulting in smaller berries and lower sugar content than from healthy vines. Powdery mildew [Uncinula necator (Schw.) Burr.] has been reported as a problem on .'Magnolia', 'Regale', and 'Tarheel' in Georgia and North Carolina (Lane, 19776; Poling et al., 1985). These diseases have been controlled with cultural practices and fungicides, although the number of fungicides registered for use on muscadines has decreased in recent years.

Muscadines are more resistant to Pierce's disease (Xyella fastidiosa Wells et al.) than Euvitis grapes, but the disease has been noted in muscadines and has been associated with vine death in some cases (Hopkins et al., 1974). The causal organism of crown gall [Agrobacterium tumefaciens (E.F. Smith \& Townsend) Conn. Biovar. 3] has been found as a latent, systemic infestation in nearly all muscadines vines tested (Griffin and Graves, 1988). However, actual gall formation and associated vine injury or death are generally only induced after winter injury and are not frequently observed. The disease is most apt to be a problem where low winter temperatures are limiting. No practical controls exist for Pierce's disease or crown gall. Virus diseases have not been reported in muscadines, but it is likely that they occur.

Insect control is primarily limited to grape root borer (Vitacea polistiformis Harris) (Dutcher et al., 1988; McGiffen and Neunzig, 1985). Control of this pest is extremely difficult because of the subterranean feeding of larvae on roots and the lack of distinct early symptoms (All et al., 1987). Early claims that muscadines were immune to grape root borer have been shown to be erroneous. No complete control strategy has been developed, but partial control is achieved with a soil drench of chlorpyrifos insecticide (Lorsban-4E, Dow, Midland, Mich.) around the trunk, in combination with cultural practices such as weed control and temporary soil mounding (All et al., 1987). Pierce's disease is vectored by sharpshooter leafhoppers (family Cicadellidae, subfamily Tettigelinae), but control of these insects is difficult (Pearson and Goheen, 1988). Other pests, such as mites, aphids, grape flea beetle (Altica chlybea Ill.), grape curculio (Craponius inaequalis Say), and grape berry moth (Endopiza viteana Clemens) are occasional problems and are controlled only if significant injury is observed (Hegwood et al., 1983; Ferree et al., 1983; Poling et al., 1987; Savage, 1941).

\section{HISTORY OF PRODUCTION AND USE}

The muscadine industry has experienced fluctuations closely tied to sales of muscadine wine (Gohdes, 1982; Morton, 1988; Reimer, 1909). In 1810, Washington County, N.C., produced 5176 liter (1368 gallons) of wine from native grapes, most of it from 'Scuppernong' (Reimer, 1909). The industry continued to grow, with vineyards in North Carolina as large as 243 ha (Reimer, 1909). Until national prohibition, $\approx 60 \%$ of total muscadine production was used for wine (Gohdes, 1982; Husmann and Dearing, 1916). "Virginia Dare", produced by Paul Garrett, was the most popular wine in the United States before prohibition (Gohdes, 1982). This wine was initially pure muscadine, but later became a blend of muscadine and California $V$. vinifera. The influence of Garrett on the muscadine industry is described by Gohdes (1982). Adoption of prohibition, first at the state level, and then nationally in 1919 with passage of the Volstead Act and the 18th Constitutional Amendment, brought an end to commercial wine production (Gohdes, 1982). However, increased demand for home wine making actually led to a boom in both East and West Coast grape production. The boom lasted until 1926, when grape prices dropped due to over-production, which was followed by the Great Depression, when many vineyards were abandoned. National prohibition ended in 1932 with adoption of the 21st Constitutional Amendment, but prohibition forces remained strong in the South and the muscadine industry did not rebuild. In 1935, the Federal Emergency Relief Administration began a program to promote muscadine fruit and wine production as an aid to Southern families on Rural Relief and to agronomic growers facing economic disaster with cotton, tobacco, and other crops (Gohdes, 1982). The plan called for planting 2 million vines. The problems of mass propagation on this scale were described by Woodroof (1936). Some of these grapes were planted and brought into production; however, the program as a whole-was not successful and was strongly opposed by prohibition forces.

Significant expansion of muscadine acreage occurred in the early 1960 s and continued through the early 1980 s with increased national consumption of wine (Brooks, 1978; Gohdes, 1982; Poling et al., 1987). Again, muscadine production, principally for wine, was seen as a means to aid depressed state economies and as a profitable alternative crop for agronomic growers. In 1965, North Carolina appropriated funds to stimulate research on breeding, production, and marketing of muscadines (Gohdes, 1982). Muscadine vineyards in North Carolina increased from 240 ha in 1968 to $>1000$ ha in 1976 . In 1978 , muscadine production in Georgia and South Carolina included 300 and 200 ha, respectively, with less production in Alabama, Arkansas, Florida, and Mississippi (Brooks, 1978). Major commercial use of muscadines remained wine production, but fresh fruit sales were increasing in importance. As recently as the early 1970s production in Georgia and the Carolinas depended on the old cultivars Hunt, Scuppernong, and Thomas (U.S. Dept. of Agriculture, 1973). With expansion of the industry, the leading cultivars in North Carolina shifted by 1976 to 'Carlos' (47\%), 'Magnolia' (20\%), and 'Scuppernong' (12\%), followed by 'Fry', 'Higgins', 'Hunt', and 'Noble' (Gohdes, 1982). Prices paid for fruit by wineries declined and muscadine production in North Carolina fell to 688 ha by 1981 (Poling et al., 1987). The important cultivars in North Carolina in 1985 were the same as in 1976, but 'Magnolia', and especially 'Scuppernong', were decreasing in importance (Poling et al., 1985). Carroll (1985) recently estimated that bronze cultivars grown for wine made up $96 \%$ of North Carolina production. In 1980, fresh fruit was reported as the primary use for muscadines in Georgia, based largely on 'Fry' (Phatak et al., 1980). Recent development of a major juice plant in Mississippi has provided an additional stimulus to the muscadine industry. Production in Mississippi increased from 45 ha in 1984, primarily for small wineries, to $\approx 340$ ha in 1988 (G. Feltenstein, personal communication). Expansion of muscadine vineyards is continuing in Mississippi and is 
expected to exceed 500 ha in 1990. Total grape production (bunch plus muscadine) in Arkansas, Georgia, North Carolina, South Carolina, and Missouri averaged 14,800 t/ year during 1984 through 1986 (U.S. Dept. of Agriculture, 1987), which represented $0.3 \%$ of total U.S. production, or $11 \%$ of grapes produced in Eastern states.

Table 1. Current muscadine production in 15 southeastern states. ${ }^{\mathrm{z}}$

\begin{tabular}{|c|c|c|c|}
\hline $\begin{array}{l}\text { Region/ } \\
\text { state }\end{array}$ & $\begin{array}{l}\text { Muscadine } \\
\text { grapes } \\
\text { (ha) }\end{array}$ & $\begin{array}{c}\text { Bunch } \\
\text { grapes } \\
\text { (ha) }\end{array}$ & $\begin{array}{c}\text { Total } \\
\text { grapes } \\
\text { (ha) }\end{array}$ \\
\hline \multicolumn{4}{|l|}{ Coastal states } \\
\hline Alabama & 146 & 16 & 162 \\
\hline Florida & 223 & 182 & 405 \\
\hline Gcorgia & .364 & 162 & 526 \\
\hline Louisiana & 81 & 0 & 81 \\
\hline Mississippi & 243 & 0 & 243 \\
\hline North Carolina & 268 & 28 & 296 \\
\hline South Carolina & 202 & 101 & 303 \\
\hline Subtotal & 1527 & 489 & 2016 \\
\hline Percent & 76 & 24 & \\
\hline \multicolumn{4}{|l|}{ Interior states } \\
\hline Arkansas & 40 & 1275 & 1315 \\
\hline Kentucky & 0 & 40 & 40 \\
\hline Missouri & 0 & 607 & 607 \\
\hline Oklahoma & 0 & 61 & 61 \\
\hline Tennessee & 18 & 93 & 111 \\
\hline Texas & 20 & 1882 & 1902 \\
\hline Virginia & 4 & 494 & 498 \\
\hline West Virginia & 0 & 4 & \\
\hline Subtotal & 82 & 4456 & 4538 \\
\hline Percent & 2 & 98 & \\
\hline \multicolumn{4}{|l|}{$\begin{array}{l}\text { Total, all south- } \\
\text { eastern United }\end{array}$} \\
\hline States & 1609 & 4945 & 6554 \\
\hline Percent & 25 & 75 & \\
\hline
\end{tabular}

SURVEY AND CURRENT STATUS OF THE MUSCADINE INDUSTRY

I conducted a survey in 1988 to gain a more detailed picture of the bunch grape and muscadine grape industries in the southeastern United States, Experiment station researchers and extension specialists dealing with grapes in 15 states (Table 1) were contacted and asked to provide the following information for each state: 1) An estimate of the number of hectares producing muscadine and bunch grapes; 2) the most common muscadine cultivars grown; 3) primary uses and markets for grapes; and 4) primary problems of the muscadine and bunch grape industries.

Muscadine hectarage in the southeastern United States is estimated at > 1600 ha, 25\% of the total Vitis hectarage in these states. Interior southeastern states have more than twice the hectarage of all grapes as that in coastal states. Muscadine production is concentrated in the coastal states, accounting for $2 \%$ of the total grape hectarage in interior states and $76 \%$ in coastal states. States with $>200$ ha of muscadine grapes were (most to least) Georgia, Mississippi, North Carolina, Florida, and South Carolina. Major bunch grape-producing states in the South are Texas, Arkansas, Missouri, and Virginia, with major emphasis on $V$. vinifera for wine production. In general, muscadines are grown where Pierce's disease is limiting and American and French-American hybrid Euvitis grapes are grown where cold injury is limiting. Vitis vinifera is preferred because of greater profitability in wine production and is grown where neither Pierce's disease nor cold injury is limiting.

A quantitative comparison of relative cultivar importance is not possible because muscadine production and hectarage statistics for the region are not available. However, cultivars were grouped qualitatively, based on the number of states listing each cultivar as important (Table 2). Currently, the two most important cultivars are 'Carlos' and 'Magnolia' (Group A). Nine additional cultivars also ranked highly, being listed in five to six states (Group B) or three to four states (Group C). The 14 cultivars in Group $\mathrm{D}$ were listed in commercial production in one or two states. Not listed are many cultivars that are in minor commercial production or are grown in backyards. Many newly released cultivars are being planted and will change cultivar ranking in the future. 'Doreen' is a new cultivar increasing in importance, while 'Hunt', 'Magnolia', and 'Scuppernong' are examples of important older cultivars that are being replaced. 'Fry' remains the primary cultivar for fresh-market production. Current expansion of muscadine production in Mississippi is based heavily on 'Carlos' and 'Doreen', but many other cultivars are also being planted. Primary characteristics and uses of the more-important or well-known cultivars are summarized in Table 3. Current problems and strengths of the muscadine-industry are summarized in Table 4. Many of the environmental and marketing problems listed are also factors limiting bunch grape production.

Commercial interests continue to demand improved cultivars and cultural methods for muscadine production. Cultural methods developed for bunch grapes often cannot be directly applied to muscadines due to marked genetic differences between Muscadinia and Euvitis. Continued commercial development depends heavily on research to improve production and processing methods, and to develop superior cultivars for fresh market and for processing. Work with Muscadinia x Euvitis hybrids will also be important in developing new rootstock and fruiting cultivars for both bunch grape and muscadine production.

Table 2. Primary muscadine cultivars grown by state. ${ }^{\mathrm{z}}$

\begin{tabular}{|c|c|c|c|c|c|c|c|c|c|c|}
\hline Group & Cultivar & Alabama & Florida & Georgia & Mississippi & $\begin{array}{c}\text { North } \\
\text { Carolina }\end{array}$ & $\begin{array}{c}\text { South } \\
\text { Carolina } \\
\end{array}$ & Tennessee & Texas & Virginia \\
\hline \multirow[t]{2}{*}{ A } & Carlos & $*$ & $*$ & $*$ & $*$ & $*$ & $*$ & & $*$ & \\
\hline & Magnolia & $*$ & * & * & $*$ & * & * & & & * \\
\hline \multirow[t]{4}{*}{ B } & Fry & * & $*$ & * & $*$ & + & & & * & \\
\hline & Higgins & * & & * & + & + & & & * & \\
\hline & Sugargate & + & + & & + & & & & * & * \\
\hline & Summit & * & * & * & + & & & & * & \\
\hline \multirow[t]{5}{*}{$\mathrm{C}$} & Cowart & + & & * & & & & & $*$ & \\
\hline & Doreen & & & & * & + & & & + & \\
\hline & Hunt & + & & + & & + & & & & * \\
\hline & Jumbo & + & * & * & * & & & & & \\
\hline & Noble & + & * & & * & * & & & & \\
\hline \multirow[t]{5}{*}{$\mathrm{D}$} & Albemarle & & & & & + & & & & \\
\hline & Dixie & & * & & & + & & & & \\
\hline & Dixiered & & * & & + & & & & & \\
\hline & Farrer & & + & & & & & & & \\
\hline & Granny Val & & + & & & & & & & \\
\hline \multirow{8}{*}{ - } & $\begin{array}{l}\text { Nesbitt } \\
\text { Regale }\end{array}$ & & * & & & + & & & * & \\
\hline & Roanoke & & & & & + & & & & \\
\hline & Scuppernong & & & + & & * & & & & \\
\hline & Sterling & & & & $*$ & * & & & & \\
\hline & Tarheel & . & & & & + & & & & * \\
\hline & Triumph & & * & & & & & * & & \\
\hline & Watcrgate & & & & + & & & & & \\
\hline & Welder & & * & & & & & & & \\
\hline
\end{tabular}

${ }^{\mathrm{Z} \text { Information based on responses of muscadine researchers and extension specialists surveyed in each state. Group indicates approx- }}$ imate overall cultivar importance. Cultivar importance in each state is estimated as primary $\left(^{*}\right)$ or secondary $(+)$. 
Table 3. Characteristics and primary uses of important or well-known muscadine cultivars.

\begin{tabular}{|c|c|c|c|c|c|c|c|c|c|c|}
\hline \multirow[b]{2}{*}{ Cultivar } & \multirow{2}{*}{$\begin{array}{l}\text { Average } \\
\text { vine } \\
\text { vigor }\end{array}$} & \multirow[b]{2}{*}{$\begin{array}{c}\text { Flower } \\
\text { type }\end{array}$} & \multirow[b]{2}{*}{$\begin{array}{c}\text { Fruit } \\
\text { colory }\end{array}$} & \multirow[b]{2}{*}{$\begin{array}{l}\text { Berry } \\
\text { size }^{\mathbf{x}}\end{array}$} & \multirow[b]{2}{*}{$\begin{array}{c}\text { Average } \\
\text { yield }\end{array}$} & \multirow[b]{2}{*}{$\begin{array}{l}\text { Harvest } \\
\text { period }^{w}\end{array}$} & \multicolumn{4}{|c|}{ Primary use ${ }^{v}$} \\
\hline & & & & & & & Wine & Juice & Process & $\begin{array}{l}\text { Fresh, } \\
\text { U-pick }\end{array}$ \\
\hline$\overline{\text { Carlos }}$ & High & Per & $\mathrm{Brz}$ & Med & High & Early & $*$ & $*$ & + & $*$ \\
\hline Cowart & Med & Per & Blk & $\mathrm{Lrg}$ & Med & Mid & & & 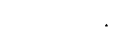 & * \\
\hline Doreen & VHigh & Per & $\mathrm{Brz}$ & Small & High & Late & * & * & * & \\
\hline Fry & Low & Fem & $\mathrm{Brz}$ & $\operatorname{Lrg}$ & High & $M-L$ & & & $\cdot$ & * \\
\hline Higgins & Med & Fem & $\mathrm{Brz}$ & $\mathrm{Lrg}$ & High & Mid & & & & * \\
\hline Hunt & VHigh & Fem & Blk & Med & Med & Early & $*$ & & & \\
\hline Jumbo & Med & Fem & Pur & VLrg & VHigh & Mid & & & * & $*$ \\
\hline Magnolia & Med & Per & $\mathrm{Brz}$ & Med & High & Mid & * & * & * & \\
\hline Noble & High & Per & Blk & Small & High & Early & * & & * & * \\
\hline $\begin{array}{l}\text { Scúpper- } \\
\text { nong }\end{array}$ & High & Fem & $\mathrm{Brz}$ & Med & Low & Mid & + & + & + & \\
\hline Sterling & Med & Per & $\mathrm{Brz}$ & Med & High & Mid & + & * & + & \\
\hline Sugargate & Med & Fem & Pur & VLrg & Low & Early & & & & * \\
\hline Summit & High & Fem & $\mathrm{Brz}$ & $\operatorname{Lrg}$ & High & Mid & & + & + & * \\
\hline Tarheel & High & Per & Blk & Small & High & Mid & * & $*$ & $*$ & \\
\hline Watergate & Med & Fem & $\mathrm{Brz}$ & VLrg & High & Mid & & & & * \\
\hline
\end{tabular}

${ }^{2}$ Flower type is perfect (Per) or female (Fern).

${ }^{y}$ Fruit color is bronze (Brz), purple (Pur), or black (Blk).

${ }^{x}$ Fruit size is based on average berry fresh weight: Small ( 2.1 to $4.0 \mathrm{~g}$ ), Med (4.1 to $6.0 \mathrm{~g}$ ), $\operatorname{Lrg}$ (6.1 to $8.0 \mathrm{~g}$ ), $\mathrm{VLrg}$ (8.1 to 10.0

g) .

${ }^{\text {w} H a r v e s t ~ p e r i o d ~ i s ~ E a r l y ~(25 ~ A u g .-9 ~ S e p t .), ~ M i d-s e a s o n ~(10-24 ~ S e p t .), ~ o r ~ L a t e ~(25 ~ S e p t .-5 ~ O c t .) . ~}$

${ }^{v}$ Use is categorized as primary $(*)$ or secondary $(+)$.

\section{Literature Cited}

All, J.N., J.D. Dutcher, and M.C. Saunders. 1987. Control program for the grape root borer in grape vineyards of the eastern United States. Down to Earth 43:10-12.

Andersen, P.C. and B.V. Brodbeck. 1988. Water and solute fluxes through pruned muscadine grape spurs. HortScience 23:978-980.

Andersen, P.C., M.W. Byran, and L.H. Baker. 1985. Effect of two wire vertical and Geneva Double Curtain training systems on berry quality and yield of muscadine grapes. Proc. Fla. State Hort. Soc. 98:175178 .

Andrew, C.P. 1981. Effect of trellis on yield of muscadine grape cultivars. HortScience 16:422. (Abstr.)

Armstrong, W.D. 1936. New varieties and pollination of muscadine grapes. Proc. Amer. Soc. Hort.. Sci. 33:450452.

Armstrong, W.D., T.A. Pickett, and M.M. Murphy, Jr. 1934. Muscadine grapes-culture, varieties, and some properties of juice. Ga. Expt. Sta. Bul. 185.

Austin, ME. and K. Bondari. 1988. A study of cultural and environmental factors on the yield of Vitis rotundifolia. Scientia Hort.. 34:219-227.

Austin, M. E. and K. Bondari. 1989. Yield of muscadine grape cultivar Hunt as influenced by plant and row spacings and position of the male plant. Applied Agr. Res. 4:1-9.

Bailey, L.H. 1937. The standard encyclopedia of horticulture. Macmillan, New York.

Balerdi, C.F. and J.A. Mortensen. 1969. Performance of muscadine grapes (Vitis rotundifolia Mich.) in central Florida. HortScience 4:252-253.

Ballinger, W.E., E.P. Maness, A.J. Makus, and D.E. Carroll, Jr. 1974. A comparison of anthocyanins and wine color quality in black grapes of 39 clones of Vitis rotundifolia Michx. J. Amer. Soc. Hort. Sci. 99:338341.

Ballinger, W.E., W.F. McClure, W.B. Ncsbitt, and E.P Maness. 1978. Light sorting muscadine grapes (Vitis rotundifolia Michx.) for ripeness. J. Amer. Soc. Hort. Sci. 103:629-634.

Bates, R.P., J.A. Mortensen, and T.E. Cracker. 1980. Florida grapes: The next decade. Proc. Fla. State Hort. Soc. 93:120-124:

Bates, R.P., T. Tejada, and J.A. Mortensen. 1986. Effect of bunch and muscadine grape maturity on finished wine. Proc. Fla. State Hort.. Soc. 99:194-200.

Boswell, F.C., R.P. Lane, and K. Ohki. 1980. Field studies with boron on muscadine grapes. Commun. Soil Sci. Plant Anal. 11:201-207.

Bouquet, A. 1980. Vitis x Muscadinia hybridization: A new way in grape breeding for disease resistance in France. Proc. 3rd Intl. Symp. on Grape Breeding. p. 42-61.

Brightwell, W.T. and M.E. Austin. 1975a. Influence of trellis type on yield of muscadine grape. J. Amer. Soc.

Table 4. Problems and strengths of the muscadine industry.

\begin{tabular}{cc}
\hline \hline Problem & Strength \\
\hline
\end{tabular}

Environmental

Cold injury in northern range of production. Relatively drought-tolerant.

Poor tolerance to wet or heavy soil.

$\mathrm{Mg}$ deficiency common.

Fruit rots.

Grape root borer.

Pests, diseases

Broad tolerance to diseases and pests compared to Euvitis grapes.

Uneven fruit ripening.

"Wet stem scar", rapid fruit decay.

Poor fruit set due to "cap sticking" as flowers open, especially 'Sugargate' and 'Fry'.

Excessive shoot growth/fruit load.

Poor plant establishment and early growth.

Low yields due to poor cultivars, site, or vineyard management.

Unstable markets.

Low prices paid by processors.

Poor consumer familiarity with muscadines out-

side of the southeastern United States.

Large initial investment.

Significant yield not obtained until 3 to 5 years after planting.

Hort. Sci. 100:58-60

Brightwell, W.T. and M.E. Austin. 1975b. Influence of plant spacing on yield of muscadine grape. J. Amer. Soc. Hort. Sci. 100:374-376.

Brooks, J.F. 1978. Muscadine grapes in the Southeast. HortScience 13:264. (Abstr.)

Carroll, D.E. 1985. Muscadine manes: Factors influencing product quality, p. 177-197.In: H.E. Pattee (ed.). Evaluation of quality of fruits and vegetables. AVI, Westport, Conn.

Chaparro, J.X., R.G. Goldy, B.D. Mowrey, and D.J. Werner. 1989. Identification of Vitis vinifera L. X Muscadinia latundifolia Small hybrids by starch gel electrophoresis. HortScience 24:128-130.

Clark, J.R. 1981. Catch frames for harvesting muscadines. Mississippi Agr. \& For. Expt. Sta. Info. Sheet 1306.

Cook, J.A. 1966. Grape nutrition, p. 777-812. In: N.F. Childers (ed.). Temperate to tropical fruit nutrition. Horticultural Publ., Rutgers Univ., New Brunswick, N.J.

Cummings, G.A. and P. Lilly. 1984. Soil pH rate for fruit yield and elemental concentration of muscadine grapes. HortScience 19:831-832.
Davidis, U.X. and H.P. Olmo. 1964. The Vitis vinifera $x \mathrm{~V}$. rotundifolia hybrids as phylloxera resistant rootstocks. Vitis 4:129-143.

Dearing, C. 1917. Muscadine grape breeding. J. Hered. 8:409-424.

Dearing, C. 1938. Muscadine grapes. U.S. Dept. of Agr. Farmers' Bul. 1785

Dearing, C. 1947. Muscadine grapes. U.S. Dept. of Agr. Farmers' Bul. 1785

Dearing, C. 1948. New muscadine grapes. U.S. Dept. of Agr. Circ. 769.

Detjen, L.R. 1917a. Inheritance of sex in Vitis rotundifolia. North Carolina Agr. Expt. Sta. Tech. Bul. 12.

Detjen, L.R. 1917b. Pollination of the rotundifolia grapes. J. El. Mitchell Sci. Soc. 33:121-127.

Dutcher, J.D., K.C. McGiffen, and J.N. All. 1988. Entomology and horticulture of muscadine grapes, p. 73 90. In: M.K. Harris and C.E. Rogers (eds.). The entomology of indigenous and naturalized systems in ag riculture. Westview Press, Boulder, Colo.

Einset, J. and C. Pratt. 1975. Grapes, p. 130-153. In: J. Janick and J.N. Moore (eds.). Advances in fruit breeding. Purdue Univ. Press, West Lafayette, Ind. Fennell, J.L. 1940. Two North American species of Vitis. 
J. Wash Acad Sci. 30:15-19.

Ferree, M.E., R.M. Crassweller, and G.W. Krewer. 1983. Commercial muscadine grape culture. Georgia Coop. Ext. Serv. Bul. 739

Gohdes, C. 1982. Scuppernong, North Carolina's grape and its wines. Duke Univ., Durham, N.C.

Goldy, R.G. 1988. Variation in some yield determining components in muscadine grapes and their correlation to yield. Euphytica 39:39-42.

Goldy, R., R. Emershad, D. Ramming, and J. Chaparro. 1988. Embryo culture as a means of introgressing seedlessncss from Vitis vinifera to $V$. rotundifolia. HortScience 23:886-889.

Goldy, R.G., E.P. Maness, H.D. Stiles, J.R. Clark, an M.A. Wilson. 1989. Pigment quantity and quality characteristics of some native Vitis rotundifolia Michx Amer. J. Enol. Viticult. 40:253-258.

Goode, D.K., Jr., G.W. Krewer, R.P. Lanf, and J.W

Daniell. 1982. Rooting studies of dormant muscadine grape cuttings. HortScience 17:644-645.

Goode, D.Z., Jr., and R.P. Lane. 1983. Rooting leafy muscadine grape cuttings. HortScience 18:944-946.

Gray, D.J. and L.C. Fisher. 1985. In vitro shoot propagation of grape species, hybrids and cultivars. Proc. Fla. State Hort. Soc. 98:172-174

Griffin, D.E. and C.H. Graves. 1988. Seasonal distribution of Agrobacterium spp. in Vitis rotundifolia vines. Phytopathology 78:627. (Abstr.)

Griffin, D.E. and C.H. Graves. 1989. Micropropagation of muscadine and its use in the development of pathogen-free propagation stock. Proc. Mississippi Assn. Plant Pathol. Nematol. p. 5-6. (Abstr.)

Hagler, T.B. 1957. Effect of magnesium sprays on muscadinc grapes. Proc. Amer. Soc. Hort. Sci. 70:178182.

Hagler, T.B. 1949. Nutrient-element deficiency symptoms of muscadine grapes in sand culture. Proc. Amer. Soc. Hort. Sci. 53:247-252.

Harkness, E.M., R.P. Vine, M.J. Coign, and J.R. Heitz. 1987. The effect of different must treatments on muscadine juice quantity-and quality. Amer. J. Enol. Vi ticult., Meeting Rpt. p. 10. (Abstr.)

Hedrick, U.P. 1908. The grapes of New York. State of New York Dept. Agr. 15th Annu. Rpt. vol. 3, Part 2.

Hegwood, C.P., R.H. Mullenax, R.A. Haygood, T.S.

Brook, and J.L. Peeples. 1983. Establishment and maintenance of muscadine vineyards. Mississippi Coop. Ext. Ser. Bul. 913

Hopkins, D.L., H.H. Mollenhauer, and J.A. Mortensen. 1974. Tolerance to Pierce's Disease and the associated Rickcttsia-like bacterium in muscadine grape. J. Amer Soc. Hort. Sci. 99:436-439.

Husmann, G. and C. Dearing. 1916. Muscadine grapes. U.S. Dept. of Agr. Farmers' Bul. 709.

Jabco, J.P., W.B. Nesbitt, and D.J. Werner. 1985. Resistance of various classes of grapes to the bunch and muscadine grape forms of black rot. J. Amer. Soc. Hort. Sci. 110:762-765.

Lane, R.P. 1972. Recent muscadine grape releases from Georgia. Fruit Var. J. 26:38-39.

Lane, R.P. 1977a. 'Summit' muscadine grape. HortScience 12:588.

Lane, R.P. 1977b. Yield of young muscadine grapes as affected by cane pruning. J. Amer. Soc. Hort. Sci. 102:379-380

Lane, R.P. 1978. Bunch grape research in Georgia. Vinifera Wine Growers J. 5:63-65.

Lane, R.P. 1989. 'Triumph' muscadine grape. HortScience 15:322.

Lane, R.P. and R.P. Bates. 1987. 'Golden Isles', a new muscadine grape for wine. Georgia Agr. Expt. Sta. Res. Rpt. 520.

Lane, R.P. and L.F. Flora. 1979. Effect of ethephon on ripening of 'Cowart' muscadine grapes. HortScience 14:727-729.

Lanier, M.R. and J.R. Morris. 1979. Evaluation of density separation for defining fruit maturities and maturation rates of once-over harvested muscadine grapes.

J. Amer. Soc. Hort. Sci. 104:249-252.

Lee, N. and H.Y. Wetzstein. 1988. Protoplast isolation and callus production from leaves of tissue-cultured Vitis-spp. Plant Cell Rpt. 7:531-534.

Lee, N. and H.Y. Wetzstein. 1990. In vitro propagation of muscadine grape by axillary shoot proliferation. J. Amer. Soc. Hort. Sci. 115:324-329.

Liberty Hyde Bailey Hortorium. 1976. Hortus third: A concise dictionary of plants cultivated in the United States and Cananda. 3rd ed. Macmillan, New York.

Lider, L.A., H.P. Olmo, and A.C. Goheen. 1988a. Hybrid grapevine rootstock. U.S. Pat No Plant 6,166.

Lider, L.A., H.P. Olmo, A.C. Gohcen. 1988b. Hybric grapevine rootstock named 'VR 043-43'. U.S. Pat No. Plant 6,166

Loomis, N.H. 1943. The influence of time and method of pruning on yields of muscadine grapes. Proc. Amer. Soc. Hort. Sci. 42:418-420.

Loomis, N.H., M.M. Murphy, and F.F. Cowart. 1949. The effect of different methods of spur pruning upon the production and growth of muscadine grapes. Proc. Amer. Soc. Hort. Sci. 54:183-185.

Lott, W.L. 1948. Mg injection in muscadine grape vines. Proc. Amer. Soc. Hort. Sci. 52:283-288.

Lott, W.L. 1952. Mg deficiency in muscadine grape vines. Proc. Amer. Soc. Hort. Sci. 60:123-131.

Mainland, C.M. W. B. Nesbitt, and R.P. Rohrbach. 1982. Effects of dormant season hedging of three muscadine grape cultivars on production, fruit quality and vine condition. HortScience 17:501. (Abstr.)

McGiffen, K.C. and H.H. Neunzig. 1985. A guide to the identification and biology of insects feeding on muscadine and bunch grapes in North Carolina. N.C Agr. Res. Ser. Bul. 470.

Mitchell, E.N. 1979. Correlation of the force required to pick Rotundifolia berries and their soluble solids content. Arner. J. Enol. \& Viticult. 30:135-138.

Moore, J.N. and H.L. Bowden. 1976. Muscadine grapes in east-central Arkansas. Arkansas Farm Rcs. 25:4.

Mortensen, J.A. 1971. Breeding grapes for Central Florida. HortScience 6:7-11.

Mortenscn, J.A. 1980. Effects of ethephon on ease of harvest of muscadine grapes. Proc. Fla. State Hort Soc. 93:143-145.

Morton, J.K. 1988. North Carolina's viticulture history, home of America's 1st cultivated vines. Vinifera Wine Growers J. 15:248-252.

Munson, T.V. 1909. Foundations of American grape culture. T.V. Munson \& Son, Denison, Texas.

Murphy, M.M, Jr., T.A. Pickett, and F.F. Cowart. 1938. Muscadine grapes: Culture, varieties and some properties of juices. Georgia Expt. Sta. Bul. 199.

Newman, C.C. 1907. Rotundifolia grapes. South Carolina Agr. Expt. Sta. Bul. 132.

Olien, W.C. 1989. Methods of planting and vine management for rapid establishment of muscadine grapes in sandy soil. Proc. Fourth Viniculture Short Course. p. 25-29. Mississippi State Univ. Mississippi State.

Olmo, H.P 1986. The potential role of (vinifera $x$ rotundifolia) hybrids in grape variety improvement. Experientia 42:921-926.

Onokpise, O.U. and I.D. Inyang. 1987. Early pruning of muscadine and bunch grape cultivars in North Florida. Proc. Fla. State Hort. Soc. 100:310-312.

Pearson, R.C. and A.C. Goheen. 1988. Compendium of grape diseases. APS Press, St. Paul, Minn.

Phatak, S.C., M.E. Austin, and J.S. Mason. 1980. Ethephon as harvest-aid for muscadine grapes. HortScience 15:267-268.

Poling, B. 1982. A troubled muscadine industry. Facts for farm markets. Summer. p. 4-6. N.C. Agr. Ext Ser.

Poling, B., C.M. Mainland, and J.B. Earp. 1987. Muscadine grape production guide for North Carolina. N.C. Agr. Ext. Ser. Bul. AG-94.

Pratt, C. 1971. Reproductive anatomy in cultivated grapes-A review. Amer. J. Enol. Viticult. 22:92 109.

Ragland, C.H. 1940. Response of muscadine grapes to potassium and phosphorus fertilizers. Proc. Assn. Southern Agr. Workers 41:154-155.

Reimer, F.C. 1909. Scuppernong and other muscadine grapes: Origin and importance. North Carolina Agr Expt. Sta. Bul. 201

Schwartz, K. 1976. The origin and development of muscadine grape varieties. Fruit Var. J. 30:90-92.

Sherman, W.B. 1963. A morphological study of fruit abscission of the muscadine grape, Vitis rotundifolia. MS Thesis, Mississippi State Univ., Mississippi State.

Sims, C.A., R.P. Johnson, and R.P. Bates. 1988. Response of a hard-to-press Vitis rotundifolia cultivar and a hard-to-clarify Euvitis hybrid to commercial enzyme preparations. Amer. J. Enol. Viticult. 39:341-343.

Small, J.K. 1913. Flora of the southeastern United States. 2nd ed. (published by the author).

Stucky, H.P. 1919. Work with Vitis rotundifolia, a species of muscadine grapes. Georgia Expt. Sta. Bul. 133

Sudarsono, J. and R.G. Goldy. 1988. Effect of some growth regulators on the in vitro culture of three Vitis rotundifolia cultivars. HortScience 23:757. (Abstr.)

Syamal, N.B. and G.I. Patel. 1953. A wild species of grape in India. Proc. Amer. Soc. Hort. Sci. 62:228 230

Takeda, F., V. Drane, and M.S. Saunders. 1983. Sprout control in muscadine grapes. HortScience 18:237-238.

U.S. Department of Agriculture. 1973. Muscadine grapes; a fruit for the South. USDA Farmers' Bul. 2157.

U.S. Department of Agriculture. 1987. Agricultural statistics 1987. U.S. Govt. Printing Office, Washington D.C.

Walker, M.A., J.A. Wolpert, E.P. Vilas, A.C. Goheen, and L.A. Lider. 1989. Resistant rootstock may control fanleaf degeneration of grapevines. Calif. Agr. 43:13 14.

Weaver, R.J. 1976. Grape growing. Wiley-Interscience, New York

Williams, C.F. 1923. Hybridization of Vitis rotundifolia Inheritance of anatomical stem characters. North Carolina Agr. Sta. Tech. Bul. 23.

Williams, C.F. 1954. Breeding perfect-flowered muscadine grapes. Proc. Amer. Soc. Hort Sci. 64:274-278.

Winkler, A.J., J.A. Cook, W.M. Kliewer, and L.A. Lider. 1974. General viticulture. Univ. of Calif. Press, Berkeley.

Woodroof, J.G. 1934. Five strains of the Scuppernong variety of muscadine grapes. Proc. Amer. Soc. Hort. Sci. 32:384-385

Woodroof, J.G. 1936. Developments in growing muscadine grapes in the South. Proc. Amer. Soc. Hort. Sci. 33:447-449.

Young, W.J. 1920. Muscadine grapes: Culture and varieties. South Carolina Agr. Expt. Sta. Bul. 205. 